\title{
Penerapan Model Pembelajaran Kooperatif Tipe STAD untuk Meningkatkan Hasil Belajar Siswa Kelas V Mata Pelajaran IPS
}

\author{
Dini Dwi Junistira \\ Universitas Nahdatul Ulama Kalimantan Timur, Indonesia \\ E-mail:miss.junistira@unukaltim.ac.id
}

\begin{tabular}{l}
\hline Article Info \\
\hline Article History \\
Received: 2021-12-27 \\
Revised: 2022-01-22 \\
Published: 2022-02-04 \\
\\
Keywords: \\
Learning model; \\
Cooperative; \\
STAD type; \\
Learning outcomes; \\
IPS.
\end{tabular}

Artikel Info

Sejarah Artikel

Diterima: 2021-12-27

Direvisi: 2022-01-22

Dipublikasi: 2022-02-04

Kata kunci:

Model Pembelajaran;

Kooperatif:

Tipe STAD;

Hasil belajar;

IPS.

\begin{abstract}
This research was conducted with the aim of explaining the learning and learning conditions of the low learning outcomes of students caused by the lack of enthusiasm of students in learning as the use of the STAD type cooperative method. The type of research method used is Classroom Action Research (CAR) with 2 cycles, each cycle consisting of planning, implementing action, class $\mathrm{V}$ research with a total of 33 students. Sources of data derived from photos and instruments used are observations and field notes. The initial results of this study for the pre-cycle showed that there were social studies learning outcomes for class V with a KKM score of 75. Student learning outcomes in the first cycle at the first meeting were 13 students who achieved the KKM score in a percentage of only $39.39 \%$. Followed by the second meeting of students who achieved the KKM score increased to 15 people with a percentage of $45.45 \%$. Furthermore, at the third meeting, student learning outcomes increased again with the number of students who reached the KKM of 19 students with a percentage of $57.57 \%$. In the second cycle consisting of three meetings, at the first meeting there were 23 students who achieved the KKM score with a percentage of $69.69 \%$. Followed by the second meeting there were as many as 26 students who completed with a percentage of $78.78 \%$. Because it has not achieved $80 \%$ success, the third meeting was continued. There was a very significant occurrence at the third meeting, as many as 31 students achieved the KKM score with a percentage of $93.93 \%$. Thus, it can be said that the STAD type cooperative method was found to improve the learning outcomes of fifth grade students and were able to obtain the second cycle.
\end{abstract}

\begin{abstract}
Abstrak
Penelitian ini dilakukan dengan tujuan untuk memaparkan adanya kesenjangan dan kondisi pembelajaran terutama rendahnya hasil belajar peserta didik yang di sebabkan kurangnya antusias peserta didik dalam pembelajaran sebagai penggunaan metode kooperatif tipe STAD. Jenis metode penelitian yang digunakan adalah Penelitian Tindakan Kelas (PTK) dengan 2 siklus, tiap siklus terdiri dari perencanaan, pelaksanaan Tindakan, penelitian kelas V dengan jumlah 33 siswa. Sumber data berasal dari foto dan instrument yang digunakan adalah observasi dan catatan lapangan. Hasil awal penelitian ini untuk pra siklus menunjukkan bahwa ada hasil belajar IPS kelas V dengan nilai KKM sebesar 75. Hasil belajar siswa pada siklus I pada pertemuan pertama 13 siswa yang mencapai nilai KKM dalam presentase hanya sebesar 39,39\%. Dilanjutkan pertemuan pertemuan kedua siswa yang mencapai nilai KKM meningkat menjadi 15 orang dengan presentase $45,45 \%$. Selanjutnya pada pertemuan ketiga hasil belajar siswa kembali mengalami kenaikan dengan jumlah siswa yang mencapai KKM 19 siswa dengan presentase 57,57\%. Dalam siklus II yang terdiri dari tiga pertemuan, pada pertemuan pertama siswa yang mencapai nilai KKM ada 23 siswa dengan presentase 69,69\%. Dilanjutkan dengan pertemuan kedua ada sebanyak 26 siswa yang tuntas dengan presentase sebanyak 78,78\%. Karena belum mencapai $80 \%$ keberhasilan siswa, maka dilanjutkan lagi pertemuan ketiga. Terjadi lonjakan yang sangat signifikan di pertemuan ketiga ini, sebanyak 31 siswa mencapai nilai KKM dengan presentase 93,93\%. Dengan demikina dapat disimpulkan bahwa metode kooperatif tipe STAD ternyata untuk meningkatkan hasil belajar siswa kelas V dan mampu memperoleh II siklus.
\end{abstract}

\section{PENDAHULUAN}

Penerapan penggunaan model pembelajaran yang tepat dalam mengajar merupakan penunjang penting dalam terwujudnya keberhasilan tujuan pembelajaran yang akan dicapai oleh guru. Model pembelajaran dikembangkan dari adanya perbedaan karakteristik siswa yang bervariasi, karena siswa memiliki berbagai karakteristik kepribadian, kebiasaan-kebiasaan, cara belajar yang bervariasi antara individu satu 
dengan yang lain, maka model pembelajaran tidak terpaku hanya pada model tertentu .Salah satu alternatif model pembelajaran yang bisa menjadi pilihan adalah model pembelajaran kooperatif, pembelajaran kooperatif muncul karena adanya perkembangan dalam sistem pembelajaran yang ada, pembelajaran kooperatif menggantikan sistem pembelajaran yang individual, dimana guru terus memberikan informasi (guru sebagai pusat) dan peserta didik hanya mendengarkan, dalam pembelajaran kooperatif, dua atau lebih individu saling tergantung satu sama lain untuk mencapai suatu tujuan bersama.

Dalam penelitian ini peneliti memilih suatu metode dari pembelajaran kooperatif dengan tipe STAD, pembelajaran kooperatif tipe STAD Student Team Achievement Division adalah model pembelajaran kooperatif yang mengkondisikan para siswa untuk belajar bersama dalam sebuah kelompok-kelompok kecil bertujuan untuk saling membantu, biasanya setiap kelompok terdiri dari 4-5 anggota. Model pembelajaran STAD merupakan metode atau pendekatan dalam pembelajaran kooperatif yang sederhana, baik dan cocok untuk guru yang baru mulai menggunakan pendekatan kooperatif dalam kelas, STAD juga merupakan suatu metode pembelajaran kooperatif yang efektif. Model pembelajaran kooperatif tipe STAD dicirikan oleh suatu struktur tugas, tujuan dan penghargaan kooperatif, siswa bekerja sama dalam situasi semangat pembelajaran kooperatif seperti tipe STAD dapat membantu siswa memahami konsep-konsep mata pelajaran yang sulit serta menumbuhkan kemampuan kerjasama, berpikir kritis, dan mengembangkan sikap sosial siswa. Model Pembelajaran Koperatif tipe STAD ini berpengaruh pada aktivitas dan interaksi diantara siswa untuk saling memotivasi dan saling membantu dalam menguasai materi pelajaran guna mencapai prestasi yang maksimal, guru yang menggunakan STAD mengajukan informasi akademik baru kepada siswa setiap minggu menggunakan presentasi verbal atau teks. Pembelajaran ini menekankan pada kerja sama kelompok dan diskusi yang melatih para siswa untuk berpikir kritis dan menemukkan pemikiran-pemikiran baru dari hasil diskusi kelompok mereka.

Pada kenyataannya metode pembelajaran yang kerap kali digunakan oleh guru adalah metode ceramah, tanya jawab, penugasan dan lain-lain yang ternyata berdampak kurang baik terhadap motivasi, penugasan materi dan daya serap siswa, disamping itu pelajaran IPS memer- lukan kegiatan belajar yang menyenangkan karena banyak materi yang bersifat cerita di dalam materi dan terkontrolnya proses belajar mengajar untuk bisa diserap oleh siswa dengan baik dibutuhkan waktu yang cukup lama untuk bisa berdiskusi baik dengan guru kelas maupun teman-temannya, dijumpai pula pada pembelajaran yang dilakukan di Sekolah Dasar Islam Terpadu (SDIT) Nurul 'Ilmi Tenggarong dikelas $\mathrm{V}$, bahwa hasil belajar siswa masih kurang memuaskan dan masih terdapat rendahnya pencapaian hasil belajar siswa. Terinspirasi dari temuan diatas penulis merasa perlu untuk melakukan suatu penelitian yang bertujuan meningkatkan hasil belajar melalui penerapkan pembelajaran model kooperatif tipe STAD yang dituangkan dalam sebuah penelitian yang berjudul "Upaya Meningkatkan Hasil Belajar Siswa Pada Materi Keberagaman Budaya Indonesia dengan Menggunakan Model Pembelajaran Kooperatif Tipe STAD Mata Pelajaran IPS Kelas V di SD IT Nurul 'Ilmi Tenggarong”.

\section{METODE PENELITIAN}

Penelitian ini merupakan Penelitian Tindakan Kelas (PTK), PTK dipilih karena peneliti ingin memperbaiki proses pembelajaran dengan mengidentifikasi permasalahan yang terjadi di kelas. Berdasarkan pada pendapat Wiriatmadja (2008:12) yang mengemukakan bahwa Penelitian Tindakan Kelas adalah kajian tematik dari upaya perbaikan pelaksanaan praktek pendidikan oleh sekelompok guru dengan melakukan tindakan-tindakan pembelajaran, berdasarkan refleksi mereka mengenai hasil dari tindakantindakan tersebut, dalam penelitian ini peneliti bertindak sebagai guru yang melakukan pembelajaran dengan menerapkan make a match untuk meningkatkan hasil belajar siswa.

Penelitian ini dilaksanakan dalam 2 siklus berdasarkan waktu pertemuan, setiap siklus ditempuh dalam 3 kali pertemuan. Penilaian Tindakan Kelas ini terdiri dari beberapa siklus tindakan pembelajaran berdasarkan refleksi mengenai hasil dari tindakan-tindakan pada siklus sebelumnya, setiap siklus terdiri empat tahapan yang meliputi perencanaan, pelaksanaan, pengamatan dan refleksi dengan uraian pokok kegiatan adalah sebagai berikut:

1. Menyusun rancangan tindakan dan dikenal dengan perencanaan, dalam tahap menyusun rancangan peneliti menentukan titik-titik untuk fokus peristiwa yang perlu mendapatkan perhatian khusus untuk diamati, kemudian membuat instrument pengamatan 
untuk membantu peneliti menemukkan fakta apa saja yang terjadi selama tindakan berlangsung. Jika digunakan dalam penelitian ini bentuk terpisah yaitu peneliti dan pelaksana pendidik adalah orang yang berbeda, dalam tahap menyusun rancangan harus ada kesepakatan antara keduanya. Oleh karena pelaksana pendidik adalah pihak yang paling berkepentingan untuk meningkatkan kinerja, maka pemilihan strategi pembelajaran disesuaikan dengan kebutuhan siswa agar pelaksanaan tindakan dapat terlaksana dengan tepat sasaran.

2. Pelaksana tindakan, yaitu implementasi atau penerapan rancangan didalam pelaksanaan kegiatan belajar di dalam kelas, hal ini perlu diingat adalah dalam tahap 2 ini pelaksana pendidik harus ingat dan taat pada apa yang sudah dirumuskan dalam rancangan, tetapi harus pula berlaku wajar. Tentu saja membuat modifikasi tetap diijinkan selama tidak mengubah prinsip.

3. Pengamatan, yaitu pelaksanaan pengamatan oleh pengamat sebenarnya kurang tepat kalau pengamatan ini dipisahkan dengan pelaksanaan tindakan karena seharusnya pengamatan dilakukan pada waktu tindakan sedang dilakukan, jadi keduanya berlangsung dalam waktu yang sama. Kepada guru pelaksana yang berstatus sebagai pengamat untuk melakuan umpan balik terhadap apa yang terjadi ketika tindakan berlangsung, sambil melakukan pengamatan balik ini pendidik pelaksana mencatat apa saja yang terjadi pada saat kegiatan belajar berlangsung walaupun hanya sedikit.

4. Refleksi data-data yang diperoleh dari pengamatan dikumpulkan dan segera dianalisis, berdasarkan observasi inilah, penulis yang sekaligus pendidik melakukan refleksi terhadap pembelajaran yang telah dilaksanakan. Berdasarkan hasil refleksi ini peneliti dapat mengetahui kelemahan maupun kelebihannya peserta didik sehingga dapat menentukan upaya perbaikan pada siklus selanjutnya.

\section{HASIL DAN PEMBAHASAN}

Dari hasil penelitian akan diuraikan tentang keterampilan guru, aktivitas peserta didik, sertas hasil belajar peserta didik selama penelitian berlangsung, penelitian dilaksanakan dalam dua siklus, siklus pertama dan siklus kedua, masingmasing siklus dilaksanakan tiga kali pertemuan. Hasil penelitian ini diperoleh dari observasi pada saat pembelajaran dan evaluasi yang dilaksana- kan pada akhir pembelajaran untuk melihat dan mengukur peningkatan hasil belajar, data kualitatif diperoleh dari hasil observasi pada saaat pembelajaran berlangsung yang berupa kativitas pembelajaran dan interaksi antara guru dan siswa serta kuantitatif yang diperoleh dari hasil tes evaluasi, berikut adalah hasil selama penelitian yang dilaksanakan dalam dua siklus.

1. Pembelajaran Pra Siklus

Pembelajaran pra siklus digunakan sebagai dasar observasi dalam menyusun perencanaan perbaikan yang di laksanakan dalam 2 siklus, pada tahapan ini penulis melaksanakan pembelajaran seperti biasa dengan menggunakan metode ceramah tanpa adanya refleksi dan penyusunan rencana pembelajaran. Metode pembelajaran seperti ini menyebabkan peserta didik kurang antusias terhadap pelajaran yang menyebabkan rendahnya hasil belajar. Berikut adalah presentase hasil belajar awal pra siklus kelas V SDIT Nurul 'Ilmi Tenggarong, yang disajikan dalam bentuk tabel sebagai berikut:

Tabel 1. Tabel Presetase Hasil Belajar Pra Siklus

\begin{tabular}{ccccc}
\hline \multicolumn{2}{c}{ Jumlah Siswa } & \multicolumn{2}{c}{ Presentase } & \\
$\begin{array}{c}\text { Tuntas } \\
\text { KKM }\end{array}$ & $\begin{array}{c}\text { Belum } \\
\text { Tuntas } \\
\text { KKM }\end{array}$ & $\begin{array}{c}\text { Tuntas } \\
\text { KKM }\end{array}$ & $\begin{array}{c}\text { Belum } \\
\text { Tuntas } \\
\text { KKM }\end{array}$ & KKilai \\
\hline 10 Siswa & 23 Siswa & $30,30 \%$ & $69,69 \%$ & 75 \\
\hline
\end{tabular}

Berdasarkan tabel diatas dapat dijabar-kan sebagai berikut, sebanyak 10 siswa atau $30,30 \%$ sudah tuntas dan mencapai KKM. Sebanyak 23 atau $69,69 \%$ belum tuntas dan tidak mencapai KKM, nilai KKM yang sudah ditentukan oleh sekolah untuk mata pelajaran IPS adalah 75. Untuk memperjelas pemaparan tabel tersebut, dapat dilihat diagram sebagai berikut:

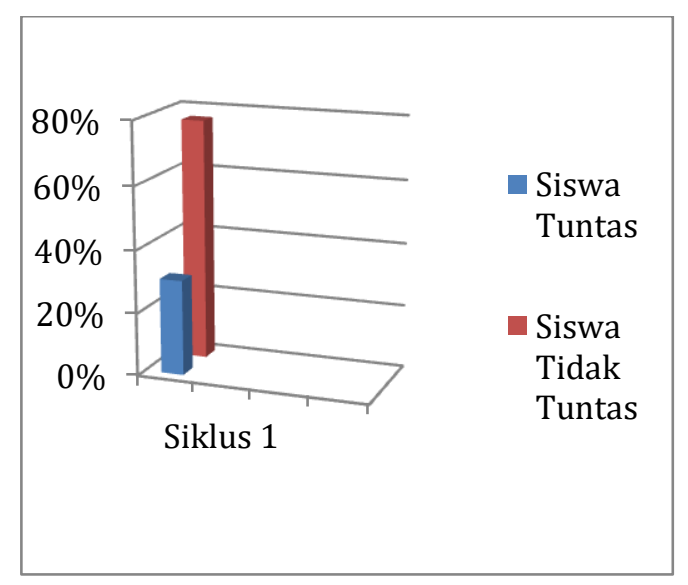

Gambar 1. Diagram Data Awal Pra Siklus 
2. Siklus Pertama

Perencanaan Tindakan Siklus Pertama yaitu sebagai berikut:

a) Guru merancang skenario pembelajaran berdasarkan metode kooperatif tipe STAD yang akan digunakan selama proses perbaikan pembelajaran.

b) Guru menyusun Rencana Pelaksanaan Pembelajaran (RPP) berdasarkan standar kompetensi dasar serta indikator yang telah dipilih untuk diajarkan.

c) Menyiapkan alat peraga dan bahan untuk melaksanakan pembelajaran dengan metode bermain peran.

d) Menyiapkan sumber belajar yang akan digunakan selama proses perbaikan pembelajaran.

e) Guru menyusun alat evaluasi untuk mengetahui tingkat keberhasilan siswa.

Berangkat dari pengamat yang telah dilakukan oleh peneliti, permasalahan yang dihadapi pada mata pelajaran Ilmu Pengetahuan Sosial (IPS) langkah langkah yang dilakukan adalah sebagai berikut:

a) Menyiapkan peserta didik untuk berdoa terlebih dahulu, kemudian mengabsen peserta didik, menyiapkan alat peraga yang digunakan beserta sumber belajar kemudian dilanjutkan dengan apersepsi.

b) Menyampaikan informasi berkaitan dengan tujuan pembelajaran yang ingin dicapai sebelum pelajaran.

c) Menyampaikan materi pembelajaran dengan menggunakan metode bermain peran sesuai dengan apa yang telah direncanakan sebelumnya.

d) Memberikan penguatan pemahaman terhadap apa yang telah di amati oleh peserta didik dari kegiatan metode bermain peran yang dilakukan oleh guru.

e) Melakukan tanya jawab seputar materi yang telah di pelajari dan memberikan soal-soal evaluasi berupa tes tertulis.

f) Menyimpulkan hasil pembelajaran bersama peserta didik dan memberikan motivasi agar peserta didik lebih giat belajar.

Saat berlangsungnya kegiatan pembelajaran, observasi dilakukan secara bersama-sama oleh penulis dan teman sejawatnya dengan menggunakan pedoman instrumen pengamatan observasi terhadap hasil belajar peserta didik dalam menggunakan metode bermain peran. Refleksi siklus pertama dilakukan untuk membahas hal-hal yang menjadi hambatan pada siklus pertama, kendala-kendala yang terjadi pada siklus 1 dipaparkan sebagai berikut:

a) Penggunaan metode kooperatif tipe STAD masih kurang optimal sehingga mengakibatkan kurangnya kerjasama antara peserta didik.

b) Keaktifan peserta didik dalam pembelajaran masih belum optimal, hal ini terlihat hanya sedikit peserta didik yang berani bertanya dan menjawab pertanyaan dari guru.

Berikut disajikan grafik Presentase Hasil Belajar Siswa Siklus 1.

Tabel 2. Data Presentase Hasil Belajar Siswa Siklus 1

\begin{tabular}{ccccc}
\hline \multicolumn{2}{c}{ Jumlah Siswa } & \multicolumn{2}{c}{ Presentase } & Belum \\
$\begin{array}{c}\text { Tuntas } \\
\text { KKM }\end{array}$ & $\begin{array}{c}\text { Belum } \\
\text { Tuntas } \\
\text { KKM }\end{array}$ & $\begin{array}{c}\text { Tuntas } \\
\text { KKM }\end{array}$ & $\begin{array}{c}\text { Buntas } \\
\text { Tuk } \\
\text { KKM }\end{array}$ & KKM \\
\hline $\begin{array}{c}19 \\
\text { Siswa }\end{array}$ & 14 Siswa & $57,57 \%$ & $42,42 \%$ & 75 \\
\hline
\end{tabular}

Pada siklus 1 pada pertemuan pertama siswa yang mencapai nilai KKM hanya sebanyak 13 siswa dalam persentase sebesar 39,39\%, dilanjutkan pertemuan kedua siswa yang mencapai nilai KKM meningkat menjadi 15 siswa dengan persentase $45,45 \%$, selanjutnya pada pertemuan ketiga hasil belajar siswa kembali mengalami kenaikan dengan jumlah siswa yang mencapai KKM menjadi 19 siswa dengan persentase $57,57 \%$, dalam siklus I yang terdiri dari tiga pertemuan bisa dilihat proses meningkatnya hasil belajar siswa dari $39,39 \%$ menjadi $45,45 \%$, dikarenakan hasil belajar siswa yang belum mencapai KKM yang ditentukan yaitu 75 dengan persentase keberhasilan siswa sebesar 85\%, maka penelitian dilanjutkan pada siklus selanjutnya yaitu siklus II.

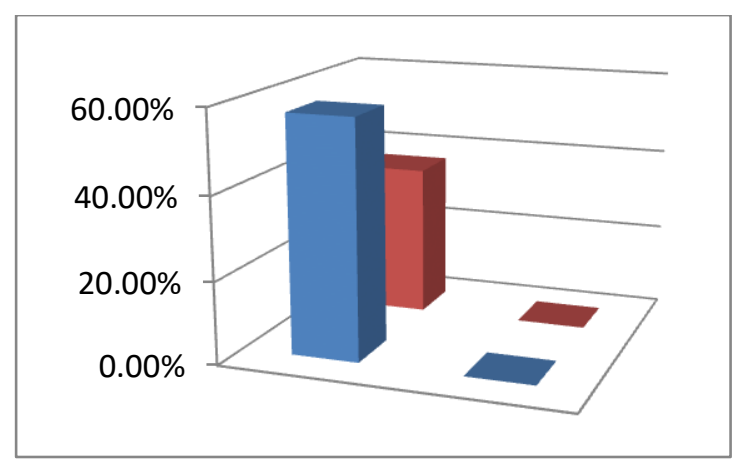

Gambar 2. Diagram Hasil Belajar Siswa Siklus I 
3. Siklus Kedua

Perencanaan Tindakan Siklus Pertama, dengan melihat hasil siklus I, maka penulis di bantu teman sejawat menyusun kembali rencana perbaikan pembelajaran pada siklus 2 dengan tahapan sebagai berikut:

a) Menyusun Rencana Pelaksanaan Pembelajaran (RPP) yang sesuai dengan materi pokok.

b) Menyiapkan sumber belajar yang relevan, alat peraga yang akan digunakan sebagai media pembelajaran ketika melakukan metode kooperatif tipe STAD.

c) Menyiapkan tes tertulis sebagai bahan evaluasi belajar.

Setelah menyusun perencanaan maka selanjutnya adalah tahap pelaksanaan, di mana peneliti melakukan hal-hal berikut :

a) Menyiapkan peserta didik untuk berdoa terlebih dahulu, kemudian mengabsen siswa lalu menyiapkan alat peraga yang akan digunakan beserta sumber belajar kemudian dilakukan apersepsi.

b) Menyampaikan informasi berkaitan dengan tujuan pembelajaran yang ingin dicapai sebelum memulai pelajaran.

c) Menyampaikan materi pembelajaran dengan menggunakan metode kooperatif tipe STAD sesuai dengan apa yang telah direncanakan sebelumnya.

d) Meminta peserta didik secara satu persatu untuk memainkan peran sesuai dengan yang sudah ditentukan.

e) Memberikan penguatan pemahaman terhadap apa yang telah di dilakukan oleh peserta didik dari kegiatan metode bermain peran yang di lakukan guru dan peserta didik.

f) Melakukan tanya jawab seputar materi yang telah di pelajari dan memberikan soal-soal berupa tes tertulis.

g) Menyimpulkan hasil pembelajaran bersama siswa dan memberikan motivasi agar siswa lebih giat belajar.

Dari pengamatan aktivitas siswa yang terjadi selama proses pembelajaran, pada siklus II ini sudah sangat mengalami peningkatan dari pada siklus I yaitu siswa semakin antusias dalam mengikuti proses pembelajaran. Terbukti peserta didik mengikuti pembelajaran dengan lebih aktif dan bersemangat, pada siklus II ini prestasi belajar siswa meningkat bila dibandingkan dengan sebelumnya dengan Kriteria Ketuntasan Minimal (KKM) yaitu 75,14.
Hasil pengamatan yang dilakukan pada siklus II ini menunjukkan bahwa siswa lebih aktif, antusisas dan serius dalam mengikuti kegiatan pembelajaran, pelaksanaan siklus II terlihat bagus dari pada siklus I, hal ini terbukti dengan semakin meningkatnya hasil evaluasi siklus di akhir siklus II. Setelah menganalisis hasil belajar siswa pada siklus II, maka kita dapat membuat tabel rekapitulasi presentase perolehan peserta didik pada tahapan siklus II pembelajaran sebagai berikut:

Tabel 3. Data Presentase Hasil Belajar Siswa Siklus II

\begin{tabular}{ccccc}
\multicolumn{2}{c}{ Jumlah Siswa } & \multicolumn{2}{c}{ Presentase } & \\
$\begin{array}{c}\text { Tuntas } \\
\text { KKM }\end{array}$ & $\begin{array}{c}\text { Belum } \\
\text { Tuntas } \\
\text { KKM }\end{array}$ & $\begin{array}{c}\text { Tuntas } \\
\text { KKM }\end{array}$ & $\begin{array}{c}\text { Belum } \\
\text { Tuntas } \\
\text { KKM }\end{array}$ & $\begin{array}{c}\text { Nilai } \\
\text { KKM }\end{array}$ \\
\hline $\begin{array}{c}31 \\
\text { Siswa }\end{array}$ & 2 Siswa & $93,93 \%$ & $6,06 \%$ & 75 \\
\hline
\end{tabular}

Berdasarkan tabel di atas dapat dijabarkan sebagai berikut, dari 33 siswa, sebanyak 29 siswa atau 87,87\% sudah tuntas dan mencapai KKM. Sebanyak 4 atau 12,12 \% belum tuntas dan tidak mencapai KKM. Untuk memperjelas pemaparan tabel tersebut, dapat dilihat diagram sebagai berikut:

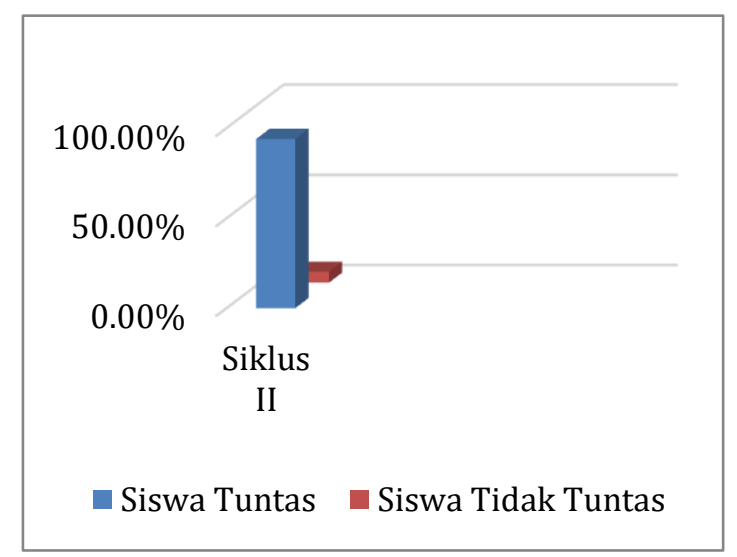

Gambar 3. Diagram Hasil Belajar Siswa Siklus II

Berdasarkan hasil belajar siswa pada siklus I, pada pertemuan pertama 23 siswa yang mencapai nilai KKM hanya sebanyak siswa dalam persentase sebesar $69,69 \%$, dilanjutkan pertemuan kedua siswa yang mencapai nilai KKM meningkat menjadi 26 siswa dengan persentase $78,78 \%$. Selanjutnya pada pertemuan ketiga hasil belajar siswa kembali mengalami kenaikan dengan jumlah siswa yang mencapai KKM menjadi 31 siswa dengan persentase 93,93\%, dalam siklus II yang terdiri dari tiga pertemuan bisa dilihat proses 
meningkatnya hasil belajar siswa dari 69,69\% menjadi 93,93\%, dikarenakan hasil belajar siswa yang sudah mencapai KKM yang ditentukan yaitu 75 dengan persentase keberhasilan siswa sebesar 85\%, maka penelitian dihentikan pada siklus II. Meningkatnya pada siklus II dengan metode kooperatif tipe STAD ternyata memberikan hasil yang memuaskan sesuai dengan yang telah direncanakan. Untuk mengetahui lebih jelas meningkatnya hasil belajar siswa dapat dilihat dari tabel berikut:

Tabel 4. Data Hasil Belajar Siswa dari Pra Siklus, Siklus I, dan Siklus II

\begin{tabular}{|c|c|c|c|c|c|}
\hline \multicolumn{6}{|c|}{ Ketuntasan } \\
\hline $\mathbf{T}$ & BT & $\mathbf{T}$ & BT & $\mathbf{T}$ & BT \\
\hline 10 & 23 & 19 & 14 & 31 & 2 \\
\hline
\end{tabular}

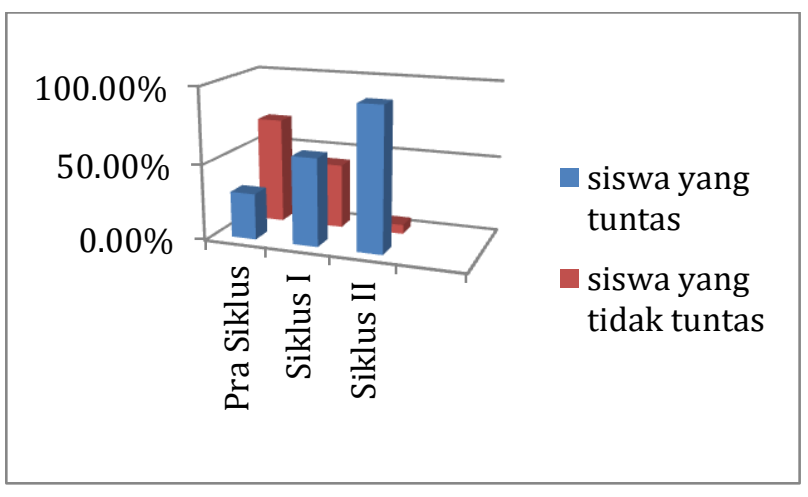

Gambar 4. Diagram Diagram Peningkatan

Hasil Belajar Siswa dari Pra Siklus, Siklus I, Siklus II

Dalam pembahasan ini diuraikan hasil penelitian mengenal meningkatnya hasil belajar IPS melalui metode kooperatif tipe STAD, berdasarkan penelitian, penggunaan metode pembelajaran metode kooperatif tipe STAD ternyata dapat meningkatkan hasil belajar IPS pada siswa kelas V SDIT Nurul 'Ilmi Tenggarong. Hal ini dikarenakan pembelajaran menggunakan metode kooperatif tipe STAD dalam proses pembelajaran memotivasi siswa sehingga membantu meningkatkan pemahaman peserta didik terhadap materi yang disampaikan oleh guru, dalam penggunaan metode kooperatif tipe STAD yang menarik perhatian peserta didik sehingga dalam penyampaian materi peserta didik tidak merasa jenuh, dengan menggunakan metode koopertif tipe STAD selama 2 siklus telah menunjukkaan meningkatnya hasil belajar siswa kelas V SDIT Nurul 'Ilmi Tenggarong melalui penerapan metode kooperatif tipe STAD dalam topik Keberagaman Budaya pada mata pelajaran IPS, ini dibuktikan dengan ada meningkatnya hasil belajar, keaktifan dalam pembelajaran pada siklus I ke siklus II. Hal ini sesuai dengan pendapat Sudjana dan Rivai (2002: 2) bahwa dengan metode pembelajaran siswa lebih banyak melakukan aktivitas selama proses pembelajaran, tidak hanya mendengarkan, menghafal, mendemonstrasikan.

Hal diatas dapat dilihat dari meningkat-nya prestasi belajar siswa dilihat dari persentase siklus I siswa yang tuntas sebesar 57,57\%\% yang pada pra siklus hanya sebesar $30,30 \%$ persentase siswa yang tuntas, dikarenakan ketuntasan belajar siswa belum mencapai $85 \%$ maka penelitian dilanjutkan pada siklus ke II, pada siklus II hasil belajar siswa meningkat sebesar 69,69\%, dari persentase siswa tuntas siklus I sebesar $57,57 \%$ menjadi $93,93 \%$, dikarenakan sudah mencapai persentase 85\% maka pada siklus II penelitian ini dihentikan. Berdasarkan hasil observasi pada pra siklus keaktifan peserta didik masih kurang, hal ini dikarenakan sebagian proses pembelajaran masih dikuasai oleh guru dan guru belum melakukan metode pembelajaran yang ada. Pada siklus I keaktifan peserta didik mulai terlihat, meskipun yang aktif hanya sedikit adalah peserta didik yang mempunyai keberanian, namun pada siklus II guru merencanakan mengaktifkan peserta didik yang belum berani, dengan memberikan kesempatan untuk bertanya dan menjawab pertanyaan-pertanyaan yang diajukan guru sehingga peserta didik lebih meningkat, pada siklus I dan II dengan adanya metode kooperatif tipe STAD peserta didik lebih tertarik dalam pembelasjara, berdasarkan pemrosesan data dengan menggunakan konsep komperasi maka dapat diperoleh hasil bahwa terdapat kecocokan dan keefektifan dalam penggunaan atau penerapan metode kooperatif tipe STAD pada mata pelajaran IPS, terbukti mampu meningkatkan hasil yang sangat signifikan.

\section{SIMPULAN DAN SARAN}

\section{A. Simpulan}

Dalam proses pembelajaran penggunaan metode kooperatif tipe STAD digunakan pada kegiatan awal, kegiatan inti dan kegiatan akhir pada siklus I, penggunaan metode kooperatif tipe STAD dalam mata pelajaran IPS dapat meningkatkan hasil belajar IPS, persentase peserta didik yang tuntas sebesar 87,87\% persentase yang di dapat, jumlah persentase ini sudah mencapai target persentase yang di harapkan yaitu $85 \%$. Hasil pengamatan siswa, dari siklus I ke siklus II mengalami 
peningkatan, ini dibuktikan dengan keaktifan siswa yang meningkat, dari uraian di atas dapat disimpulkan bahwa hasil belajar siswa kelas V SDIT Nurul 'Ilmi Tenggarong terjadi meningkat sangat signifikan dan ternyata cocok dengan menggunakan metode kooperatif tipe STAD. Terbukti mampu meningkatkan hasil belajar peserta didik.

\section{B. Saran}

Berdasarkan hasil penelitian, peneliti menyampaikan saran sebagai berikut:

1. Metode kooperatif tipe STAD dengan materi Keragaman Budaya pada mata pelajaran IPS merupakan metode yang cukup efektif untuk diterapkan di kelas, sehingga tercipta pembelajaran yang lebih menarik dan peserta didik terbantu dalam memahami materi IPS yang cenderung banyak hafalan.

2. Guru dapat menerapkan metode kooperatif tipe STAD bukan hanya pada pembelajaran IPS tapi pembelajaran yang lain agar menarik perhatian siswa.

3. Guru merancang sedemikian rupa dan memperkaya metode/pendekatan mengajar. Hal ini untuk mengantisipasi kejenuhan yang dialami siswa dan selalu memantau perkembangannya terutama dari perilaku, pemikiran dan pemahaman terhadap materi yang diajarkan.

4. Penelitian ini diharapkan dapat memberikan masukan bagi guru-guru untuk menerapkan metode kooperatif tipe STAD sebagai salah satu alternatif metode pembelajaran, karena metode pembelajaran ini efektif untuk meningkatkan aktivitas belajar siswa.

\section{DAFTAR RUJUKAN}

Arikunto, Suharsimi. 2006. Prosedur Penelitian Suatu Pendekatan Praktek. Jakarta:Rineksa Cipta.

Bukit, Herawaty. 2016. Meningkatkan Motivasi Belajar Siswa dengan Menggunakan Model Kooperatif Tipe Student Teams Achievement Division (STAD) Pada Mata Pelajaran IPS di Kelas V SDN 107402 Saentis. Jurnal Vol. 5 No. 2 Juni 2016.

Esminarto. Sukawati. Suryowati, Nur. Anom, Khoirul. 2016. Implementasi Model STAD dalam Meningkatkan hasil belajar siswa. Jurnal Vol. 1 No.1 2016.
Etin, Solihatin. 2009. Pembelajaran IPS. Bandung: Sinar Baru Algensindo.

Fatoni. 2016. Pengaruh Pembelajaran Kooperatif Tipe STAD dengan Problem Based Learning Terhadap Kerjasama dan Hasil Belajar IPS Siswa Kelas V SD. Jurnal Vol. 2 No. 1 Januari 2016.

Hamdani. 2010. Strategi Belajar Mengajar. Bandung: Pustaka Setia

Hardjono, Nyoto. Rifai, Moh. 2019. Meta-analisis Keefektifan Model Pembelajaran Student Teams Achievement Division (STAD) dalam Meningkatkan Hasil Belajar IPS Siswa SD. Jurnal. Vol. 8 No.2 Oktober 2019.

Hidayati. 2002. Metode Bermain Peran. Jakarta:Rineksa Cipta.

Kasihani, Kasbolah. 1998. Metode Penelitian Tindakan Kelas. Bandung: Alfabeta

Kristin, Firosalia. 2016. Efektifitas Model Pembelajaran Kooperatif Tipe (STAD) Ditinjau dari Hasil Belajar IPS Siswa Kelas 4 SD. Jurnal Vol. 6 No. 2 (2016).

Naviska, Rima Isti. Tastra, I Dewa Kade. Dibia, I Ketut. 2017. Pengaruh Pembelajaran Kooperatif Tipe STAD Berbantuan Media Video Pembelajaran Terhadap Hasil Belajar IPS Siswa SD Kelas V. Jurnal Vol. 5 No. 22017.

Roestiyah. N. K. 2001. Metode Bermain Peran: Bandung: Alfabeta

Rusman. 2011. Role Playing (Metode Bermain Peran). Bandung: Pustaka Setia

Samilat. Juliana Margareta. Metutu, Vindi. S. 2021. Model Pembelajaran Kooperatif tipe STAD (Student Teams Achievement Divisions) untuk Meningkatkan Hasil Belajar Siswa Sekolah Dasar. Jurnal Vol. 3 2021.

Sudjana. 2005. Penelitian dan Penilaian Pendidikan. Bandung: Sinar Baru.

Sumkmadinata. 2005. Strategi Belajar Mengajar. Bandung: Alfabeta 
Sukidin dkk. 2012. Manajemen Penelitian Tindakan Kelas. Surabaya: Insane Cendekia.

Supardi. 2011. Metode Dan Model-Model Mengajar IPS. Bandung: Alfabeta.

Syaiful, Sagala. 2008. Evaluasi Pembelajaran. Bandung: Pustaka Setia
Usman, Moh. Uzer. 2012. Menjadi Guru Profesional. Bandung: Remaja Rosdakarya.

Winkel. 2004. Evaluasi Belajar. Surabaya: Insane Cendekia.

Wiyono, Tasrif. 2008. Metode Dan Model-Model Mengajar IPS. Bandung: Alfabeta. 